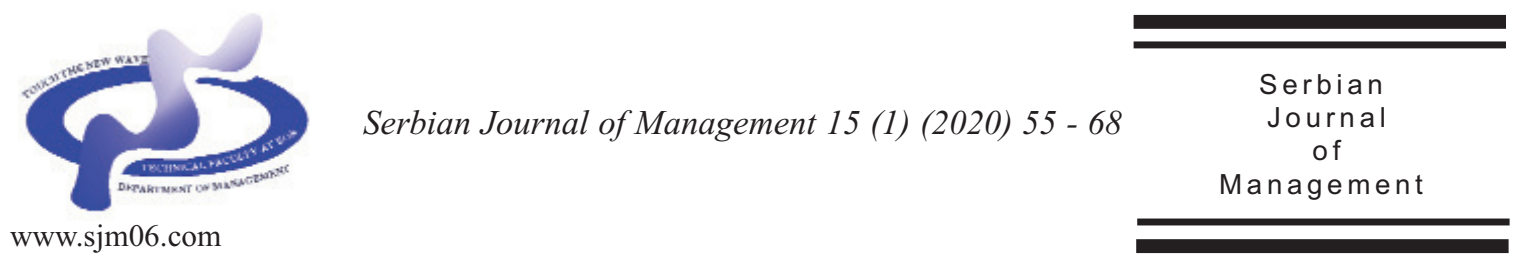

\title{
MODERN TRENDS IN MANAGEMENT OF THE BUDGET SYSTEM
}

\author{
Yerkezhan Bitoleuova $^{a}$, Dina Aibossynova ${ }^{b}$, Gulmira Kabdullinac, \\ Manshuk Baimukhashevad and Raikhan Tazhibaeva ${ }^{\mathrm{e}}$
}

\author{
$a_{\text {L.N. Gumilyov Eurasian National University, }}$ \\ Satpayev Str., 2, Nur-Sultan, Kazakhstan

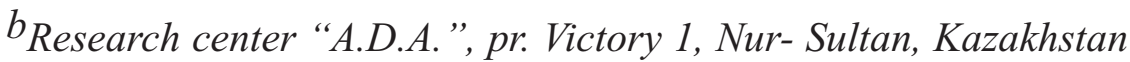 \\ ${ }^{c}$ Department of Labor economics and personnel management, South Ural State University \\ (National Research University), Lenin Ave. 76, Chelyabinsk, Russia

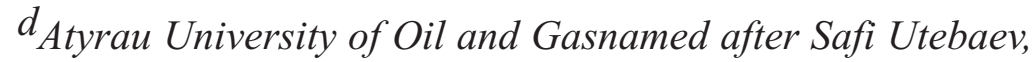 \\ Azzatyk aven., 1, Atyrau, Kazakhstan

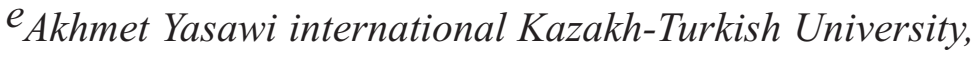 \\ B.Sattarkhanov aven., 29, Turkestan, Kazakhstan
}

(Received 12 November 2019; accepted 12 April 2020)

\begin{abstract}
The article deals with the pressing issues of the development of local self-government in the Republic of Kazakhstan at the current stage. The feature of the reforms, currently underway, is the strengthening of financial independence of local self-government bodies. First of all, it is attributed to the introduction of the independent budget at the local self-government level. The study brings into the light the systemic nature of the budget process and analyses the world's best reformation practices for the budget process. The systematic approach helps reveal the distinguishing characteristics of budget decision making in the context of costly and programme-targeted planning models. It also allows investigating the business climate adequately and finding optimal paths for development. The results from this research involve the aspects and significance of the management of the budget system of the Republic, on the basis of which the relevant conclusion has been drawn.
\end{abstract}

Keywords: budget system, budgeting, innovation, local budget, local self-government

\footnotetext{
* Corresponding author: bitoleuovayer@rambler.ru
}

DOI: 10.5937/sjm15-23985 


\section{INTRODUCTION}

Budget management is underlined by a system-based strategy for organising income and expenditures. The system upon which the strategy is based resembles a set of interconnected elements that form a goaloriented unity and interact with the environment and among them.

There are at least several dozen different definitions of a "system" that are used depending on the context, field of knowledge and research objectives. The main reason for such diversity is that a "system" is a dual concept: on the one hand, it is used to denote objectively existing phenomena. On the other hand, the concept is implemented as a method for studying and representing phenomena, that is, as a subjective model of reality (Korikov \& Pavlov, 2008)

In the context of such a duality, a problem arises: how a system can be objectively distinguished from a non-system and from the environment. There are two approaches to defining a system, descriptive and constructive. This study uses a descriptive definition of a system, which implies the presence of a system's function or purpose from the observer's point of view. The observer or a researcher is explicitly or implicitly introduced into the definition.

The process of managing public reserves is primarily oriented towards a social effect, rather than commercial profit. This goal defines the specific purpose of both a budget system and each element within it (Yan et al., 2010)

When implementing the budget policy, the government de facto organises the country's expenditures, while the revenue management is guided by the fiscal policy. The efficiency of public expenditure management (PEM) is largely determined by how well the budgeting is done, dependent upon the procedures of expenditure budget planning, approval and execution, and upon the budgetary control operations. The above once again emphasises the systematic nature of budget process. Many state economic systems currently use a line-item budgeting model that does not meet the country's needs. A specific solution to this problem calls for the introduction of performancebased budgeting or results-based budgeting model, which fundamentally changes all stages of the budget process and the very concept of PEM (Parreiras et al., 2019). Neglecting the systemic nature of the budget process, however, may provoke conflicts between agents and principals. Hence, an adequate research of budget reform proposals is required.

Creating an effective budget system is an inseparable part of the process of establishing and developing a market economy. Social and economic changes of Kazakhstan in 1990-s, have led to a profound transformation of the entire financial system of the country and its main element - the budget system. Meanwhile, the role of the budget system in a market economy, as one of the most significant regulatory instruments, under conditions of decreased opportunities to influence economic processes of the country through administrative methods, has risen considerably. The creation of the four-level budget system, including the Republican budget, the regional budget, the budgets of the city of republic significance, the capital, the district budget (the city of regional significance), budgets of the city of district significance, the village, the rural county, has become the most important area of reform of state finances.

One of the significant areas of adopted 
innovations is the phased implementation of the independent budget at the level of the cities of district significance, villages, rural counties, as well as the further empowerment of local self-government bodies in the sphere of budgeting (Fomina et al., 2019).

Changes in the system of local selfgovernment are closely tied to the overall reform of the budget process, which aims to create conditions and prerequisites to maximise efficiencies in the area of state and municipal finances. In the context of the transformation of the budget process the issue of improving the efficiency of local budgets has become relevant.

\section{LITERATURE REVIEW}

The following foreign economists made a fundamental contribution to the development of a theory of budgetary management and budgetary efficiency in the framework of national policy:

The application of "Assessing the investment potential of municipal education via the SWOT analysis of municipal training methodology" allows one to develop longterm strategies for the socio-economic development of regions (Latysheva et al., 2018).

The methods of reducing the tax burden allow one to increase financial resources to speed up the pace of development (Ponomareva, 2013).

The scientific, methodological and applied aspects of state management of social and economic processes and relations are studied (Razberg, 2009).

The distribution of local budgets (taking into account the current state of economy and society) is seen as deficit financing of the state budget in the framework of progressive development (Afanasyev, 2000; Afanasyev \& Krivogov, 2007).

The problems and prospects of the development of state and municipal finances at the regional level are reflected in misuse of budget funds as a result of budget reform (Vasilieva, 2011).

Principal approaches in the organisation of local budgets are aimed at the balance and stability of all levels of the state budget (Igonina, 2003).

Budget alignment can solve the following pressing issues of the Russian Federation:

- budget reform;

- forms and methods of financial support to subjects of the Russian Federation;

- budget structure of the Russian Federation (Sabitova, 2002, 2004, 2005).

Addressing the issues of the budget process, reform of local budgets and local self-government is reflected in the works of Kazakhstan scientists, such as:

The issues, related to local selfgovernment, as potential of the social and economic development of the Republic are studied in the work of Asaubayev (2016).

The budget planning and forecasting in the Republic of Kazakhstan allow influencing the achievement of results (Zhunusova et al., 2014).

Nonetheless, the analysis of publications demonstrates that this area of research has not been fully studied, for which the present study aims at further exploration of modern trends of social and economic development of the Republic of Kazakhstan.

\section{EXPERIMENTAL}

Given the systemic nature of the budget process, the most appropriate research 
method is considered a systematic approach to identifying structural relationships between variables and elements of the system under study. The relevance of selected approach lies in the fact that considering categories within the framework of systematic analysis allows logical consistency in decision-making at the state level of management and thus, a decision between well-defined alternative plans for economic, industrial, regional, and national development.

The decision-making procedure occurs in the following stages:

1. Identifying the problem of forming the revenue base of local budgets

2. Setting goals while planning the draft local budget

3. Developing criteria for achieving goals in planning documents and regulatory legal acts of local governments while forming local budget revenues

4. Building models to justify decisions of problem situations and the choice of an alternative solution that takes into account various factors and criteria

5. Seeking an optimal (acceptable) solution including a set of certain characteristics, which necessarily include resource characteristics

6. Reaching agreement (coordination of all contentious issues in the distribution of budget funds at the local level)

7. Planning actions to use budget funds and increase revenues to local budgets

8. Approving an action plan on the functioning of the financial mechanism at the local level

9. Managing the formation of local budget revenues in the context of centralisation

10. Evaluating the effectiveness of local budget funds use
The study also uses the International Monetary Fund techniques (International Monetary Fund, 2007a, 2007b) and OECD methods (OECD, 2002) that permit the evaluation of transparency in the public sector.

\section{RESULTS}

The problems of budgeting have been relevant since the establishment of independent Kazakhstan and have been subject to reforming of legislature, however, some issues stayed in the shadows of key problems, specifically the problem of efficiency of budgets, while the execution of the budget is the main objective of budgeting, the indicator of "quality" of local power, the key indicator of efficiency and acceptability of the system of legal and financial support for local budgets and local self-government. Nowadays, Kazakhstan is implementing best practices of OECD countries, in the field of budget planning as well.

Thus, according to the data of the OECD's Comprehensive Country Profile for Kazakhstan, the reduction in oil revenues and fiscal stimulus considerably weakened the state budget of Kazakhstan, although it was compensated slightly due to the fall in the exchange rate. The decrease in oil prices and overall economic conditions in 2015 resulted in the reduction of the revenues of the Government, although not as dramatically as the global financial crisis and the associated political measures did in 2009. Revenues hit their lowest point in September 2015 , and were $8.6 \%$ lower than the peak (in 12-month sliding scale), mainly due to the reduction of revenues, associated with oil, to $28 \%$, as well as a $9 \%$ drop in non-oil and gas 
revenues, associated with domestic consumption. These trends have reduced state revenues to their lowest level with respect to GDP since the beginning of the 2000s. The government sought to compensate for the decline in private demand by stimulating government expenditures. Nominal expenses grew very rapidly in 2013 and somewhat more moderately in 2014, before stabilising due to economic conditions and the deterioration of revenues in 2015. Current salary costs and purchase of goods and services went up, while other major and other current expenditures were steady and transfer increased according to trend rates. Consequently, spending increased to $21.6 \%$ of GDP, the highest level since the global economic downturn of 2009-2010. Indeed, these efforts to support the economy contrasted with the global financial crisis, when nominal spending went down by $7 \%$ in 2009, before a sharp recovery. After accounting for financial transactions, these trends in revenue and expenditure shifted the budget from surplus of 5.0\% of GDP in 2013 to the estimated deficit of $5.3 \%$ of GDP in 2015 and the projected deficit of $4.0 \%$ in 2016. (Figure) This is where a fiscal impulse is set at $4.5 \%$ of GDP or 3.8 trillion tenge (21 billion US dollars) at an average annual exchange rate for two years.

Different supporting economic programmes of the Government in a short time attracted financial assets of the state. The total amount of state-owned offshore financial assets dropped by $\$ 14.9$ billion from its peak at the end of 2014, and then stabilised at the beginning of 2016, while the Government also received $\$ 6.3$ billion in sales of external debts and also expanded domestic debt. At the beginning of 2016, the assets of the National Fund fell by $\$ 13.7$ billion from a historic peak in mid-2014 of \$ 77.3 billion, while foreign currency reserves (KIV) fell by $\$ 2.7$ billion for the same period. These reductions served as an additional factor in returning the Government to international sources to finance its deficit. The government has started issuing dollar bonds and attracting multilateral lenders since 2014.

Economic support programmes were also implemented by state entities outside the budget. The budget deficit for 2015 and for the projected 2016 requires funding in the amount of $\$ 14$ billion, compared with more than $\$ 22$ billion from various sources. Such programmes can be exemplified by concessional lending and business schemes or focused on investment programmes implemented by companies within the Baiterek and Samruk-Kazyna groups, such as Damu and the Development Bank of Kazakhstan (discussed in other sections of this report). These schemes contributed to domestic spending, expanded production capacity, and provided support to demand for tenge in foreign exchange markets.

Rating agencies noted a sharp drop in reserves stored in the national oil fund from 2014 to 2016, given that these reserves represent an important buffer against weaker revenues and economic instability. Relaxation of the rules for the use of a national fund loan so that it can be more easily exhausted may undermine the quality of the goals of stabilisation, savings and equity with respect to future generations. Indeed, the consistency of the principles of inflow and decline are important for sovereign wealth funds to play their role as sources of sustainability and reliability of countries prone to natural resource goals. This stability is the key contribution of foundations to the national economy, 
recognised in Santiago. Generally accepted principles and practices for sovereign wealth funds and in the leadership of the OECD.

Economic support measures by the Government are a reasonable response to a temporary recession, but they cannot be sustained if less favourable conditions persist. The extent and likelihood of the duration of worsening economic conditions are not expected. Figure 1 shows revenues and expenditures of the state budget, trillions of tenge, deficit of the budget, \% of GDP, excluding financial contracts. Between 2013 and 2015, forecasts of total government revenues in $2016-2018$ fell by $28 \%$ or 10 trillion. tenge or $3.5 \%$ of revised GDP (according to IMF forecasts of nominal
GDP). In all likelihood, the duration of pessimistic forecasts makes the use of reserves and loans to compensate for weak revenues unsustainable, even if the resources remain stable. The pessimistic forecast of revenues suggests that spending should be reduced and revenues will increase before the renewal of sustainable development of public finances. Regulation should also arise for the expenses of extrabudgetary state organisations that can use offshore funds; economic support can be directed to investment programmes implemented by various state structures. Achieving this requires, as the mobilisation of revenues from the domestic non-resource economy more efficient with the stabilisation of the

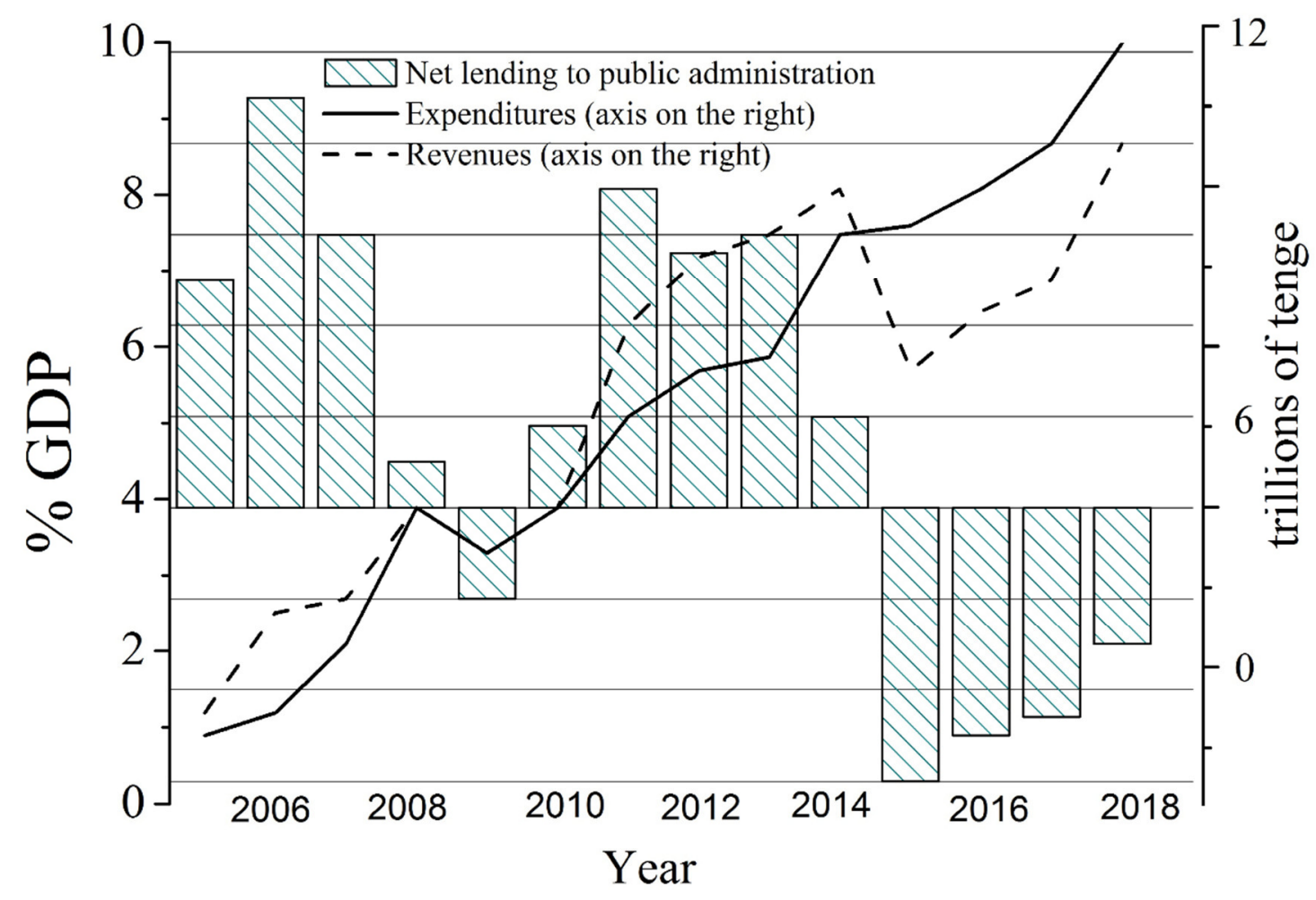

Notes: Revenues and expenditures have been adjusted for financing the transactions in accordance with the Global Financial Statistics after the IMF presentation.

Sources: IMF, sources, adjusting national data, calculations of the authors.

Figure 1. Revenues and expenditures of the state budget, trillions of tenge, deficit of the budget, \% of GDP, excluding financial contracts. 
total volume of expenditures. Total costs can be adjusted with limited impact on the supply of public goods and services when pursuing more effective policies, for example, when regulating investment and preferential credit programmes.

Figure 2 presents budget revenues and expenditures in relation to GDP in \%, 20162018. From fig. 2 it can clearly be seen, that revenues and expenditures of local budgets are quite balanced. The level of revenues and expenditures of local budgets is about at 8$9 \%$ of GDP. Analysis of Fig. 2 shows that from 2016 to 2018 there was a shortfall of Republican budget due to the drop of revenues and their fluctuations in relation to GDP: in 2016 - 16\%, in 2017 - 18\%, in 2018 - $15 \%$. Despite the decrease in the number of revenues of the Republican budget, expenditures of the Republican budget in relation to GDP experienced the growth: in 2016 - 17\%, in 2017 - 20\%, 2018 - 16\%.
Figure 2 demonstrates two crucial facts: the economic significance of local budgets, which amounted to only $1 / 10$ of the country's economy, and a high degree of efforts, made by the government in order to stabilise budget parameters on the ground.

Figure 3 presents revenues of the republican budget in relation to GDP, in \%, 2016-2018. The reduction in revenues of the Republican budget in 2016-2018 was caused by the drop of tax receipts, which traditionally accounted for a high proportion among other types of revenues, and it required an infusion of resources of the National Fund. In recent years, the situation has changed a bit in favour of an increase in tax receipts and "mirrored" drop in revenues of transfers. As a result, tax receipts, which come from taxes paid by SME, are subject to volatility. This fact should be taken into account when improving the budget system and inter-budgetary relations, which include

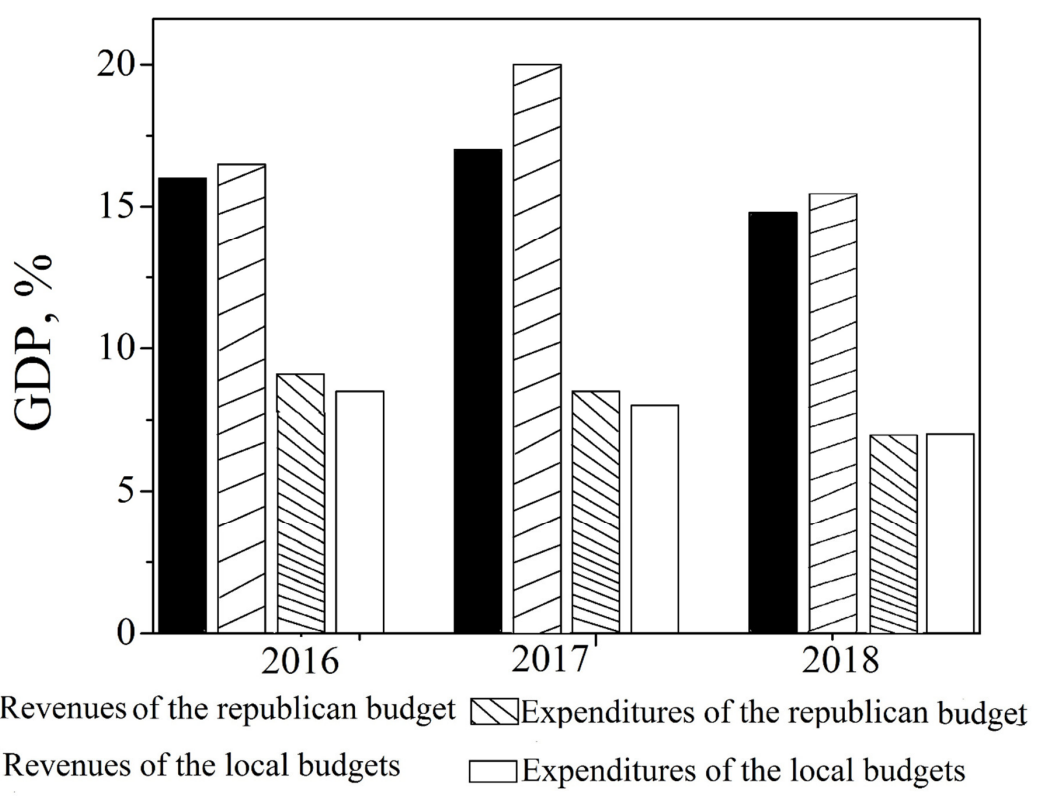

Source: Ministry of finance of the Republic of Kazakhstan, www.minfin.gov.kz, Committee of statistics of the MNE of the RK, in relation to GDP of the Republic of Kazakhstan, www.stat.gov.kz 
the formation of revenues of local budgets through corporate taxes of SME.

Figure 4 shows revenues of local budgets in relation to GDP in \%, 2016-2018. Revenues of local budgets in relation to GDP in 2016-2018 have demonstrated overdependence of local budgets on centralised transfers of the Republican budget. The proportion of transfer receipts is considerable and compatible with tax receipts, which are collected to local budgets. It can be concluded that local budgets are not self-sufficient and have limited opportunities in developing their region.

Tax receipts to local budgets in relation to GDP were less than 4\% in 2016, whereas transfers accounted for 5\% of GDP. Non-tax receipts and receipts from the sale of fixed assets have traditionally been insignificant, owing to a number of factors, such as lack and low level of non-tax payments, as well as revenues from the sale of fixed assets.
The Concept of new budget policy emphasises that transfers accounted for $61.7 \%$ on an average in the total amount of revenues of local budgets. Funding for events of a regional character from the Republican budget has risen.

Table 1 shows the percentage of various types of revenues of local budgets, in \%, 2016-2018. Indeed, as a result of the system of inter-budgetary relations in force at that time, the proportion of transfers was considerable and fluctuated in 2016-2018 from $58.24 \%$ to $47.14 \%$ of all receipts of local budgets, in other words, it amounted to almost half of revenues of local budgets.

According to the date of the Ministry of Finance of the Republic of Kazakhstan, the majority of revenues, approximately $73 \%$ of general tax receipts, goes to the Republican budget. These receipts mainly come from corporate income taxes of legal entities. The remaining part, about $27 \%$ of tax receipts, going to local budgets, comes from

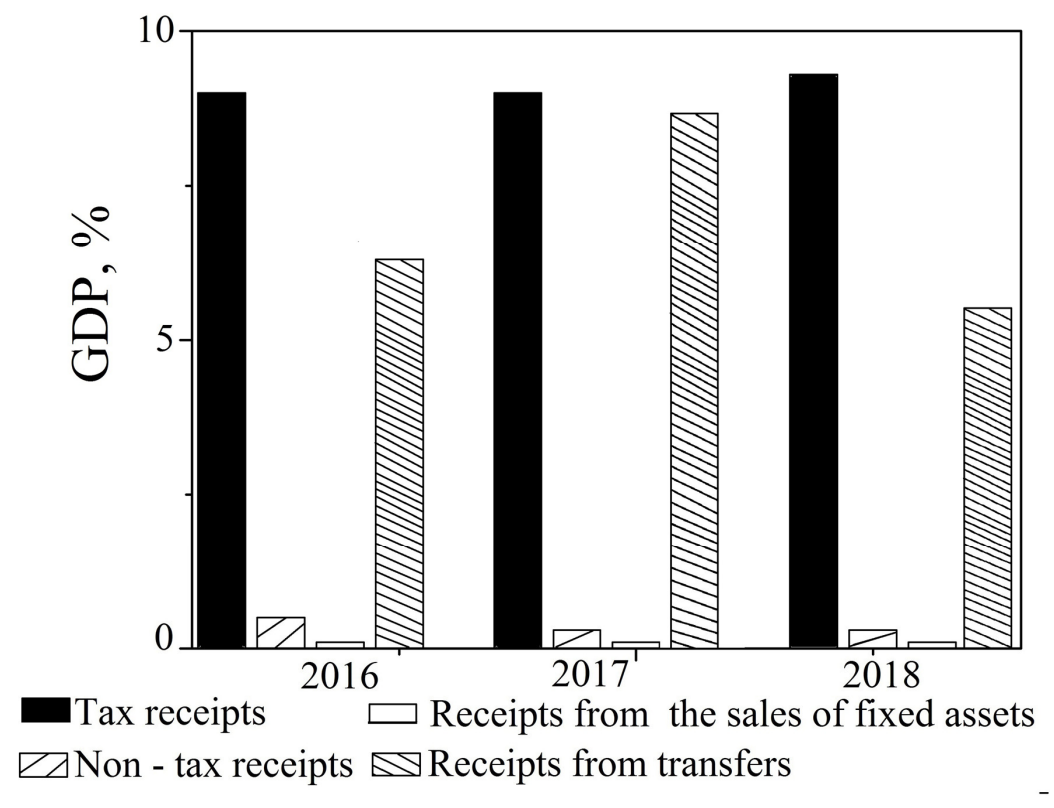

Figure 3. Revenues of the republican budget in relation to GDP, in \%, 2016-2018 


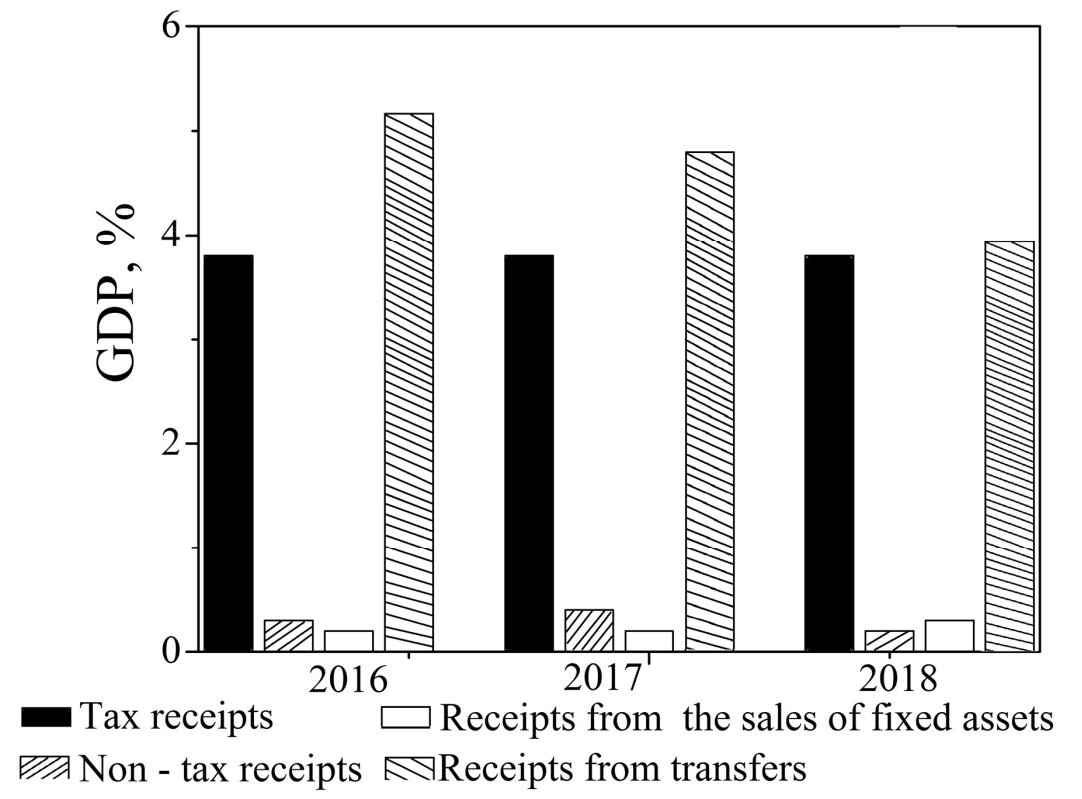

Figure 4. Revenues of local budgets in relation to GDP in \%, 2016-2018

Table 1. The percentage of various types of revenues of local budgets, in \%, 2016-2018

\begin{tabular}{|c|c|c|c|}
\hline Various types of revenues of local budgets, in \% & 2016 , in \% & 2017 , in \% & 2018, in \% \\
\hline Receipts from transfers & 58.24 & 51.27 & 47.14 \\
\hline Receipts from the sale of fixed assets & 1.16 & 2.20 & 2.12 \\
\hline Non-tax receipts & 2.11 & 2.30 & 1.83 \\
\hline Tax receipts & 38.49 & 44.23 & 48.90 \\
\hline
\end{tabular}

individual income taxes of physical persons (Table 1). A relatively small amount of corporate taxes, given the size of the economy and the activity of mining companies with billions of turnover, can be explained by the fact that all revenues coming from mining oil companies go to the National Fund, whereas remaining enterprises make up budget revenues with respect to tax receipts.

Table 2 presents revenues of the republican and local budgets, mln tenge, in 2016. Table 2 shows the obvious disparity in fiscal policy and inter-budgetary relations, according to which all tax receipts coming from various entities remain in the
Republican budget and then, without taking into account the contribution of certain entities, are distributed among all regions of Kazakhstan. There is a lack of motivation to develop entrepreneurship, small and medium business in regions, as local authorities receive the guaranteed transfer. Additionally, the presence of SME, which play an important social role in people's employment and fiscal role as tax subjects, does not directly guarantee the existence of adequate infrastructure for the development of business. A clear disparity can be seen between interests of authorities and businesses in regions, as well as revenues to local budgets regardless of efforts for the 
Table 2. Revenues of the republican and local budgets, mln tenge, in 2016

\begin{tabular}{lcccc}
\hline Name & $\begin{array}{c}\text { Republican } \\
\text { budget }\end{array}$ & $\begin{array}{c}\text { \% of total } \\
\text { payments }\end{array}$ & $\begin{array}{c}\text { Local } \\
\text { budgets }\end{array}$ & $\begin{array}{c}\text { \% of total } \\
\text { payments }\end{array}$ \\
\hline 1 & 2 & 3 & 4 & 5 \\
REVENUES & $\mathbf{7 6 6 2 ~ 2 2 0}$ & $\mathbf{1 0 0 \%}$ & $\mathbf{4 3 1 5 5 8 2}$ & $\mathbf{1 0 0 \%}$ \\
Tax receipts, including: & $\mathbf{4 2 7 5 8 8 7}$ & $\mathbf{5 6 \%}$ & $\mathbf{1 7 4 7 ~ 3 7 6}$ & $\mathbf{4 0 \%}$ \\
$\quad$ Corporate income tax & 1437365 & $19 \%$ & 0 & $0 \%$ \\
$\quad$ Individual income tax & 0 & $0 \%$ & 691778 & $16 \%$ \\
$\quad$ Value added tax & 495682 & $20 \%$ & 0 & $0 \%$ \\
$\quad$ Social tax & 0 & $0 \%$ & 530440 & $12 \%$ \\
$\quad$ Excise taxes & 77844 & $1 \%$ & 127387 & $3 \%$ \\
Non tax receipts & $\mathbf{2 9 8} \mathbf{2 4 3}$ & $\mathbf{4 \%}$ & $\mathbf{7 1 ~ 6 2 0}$ & $\mathbf{2 \%}$ \\
Receipts from the sale of fixed assets & $\mathbf{7 7 8 6}$ & $\mathbf{0 \%}$ & $\mathbf{5 2 ~ 4 3 8}$ & $\mathbf{1 \%}$ \\
Receipts from transfers & $\mathbf{3 0 8 0 ~ 3 0 4}$ & $\mathbf{4 0 \%}$ & $\mathbf{2 4 4 4 ~ 1 4 9}$ & $\mathbf{5 7 \%}$ \\
\hline
\end{tabular}

Table 3. Expenditures of local budgets in \%, in 2016-2018

\begin{tabular}{|c|c|c|c|}
\hline Expenditures of local budgets & 2016 , in \% & 2017 , in $\%$ & 2018 , in $\%$ \\
\hline Transfers & 4.96 & 5.21 & 7.39 \\
\hline Debt service & 0.00 & 0.06 & 0.07 \\
\hline Others & 1.92 & 2.19 & 2.59 \\
\hline Transport and communications & 6.73 & 8.55 & 9.20 \\
\hline Industry, architecture and constructions & 1.81 & 0.69 & 0.84 \\
\hline Agriculture, water management, forestry & 10.85 & 7.86 & 6.65 \\
\hline Fuel and energy, mining & 2.19 & 3.52 & 2.93 \\
\hline Culture, sport, tourism & 4.72 & 4.92 & 5.64 \\
\hline Housing & 14.65 & 16.68 & 16.94 \\
\hline Social support, social security & 3.58 & 4.22 & 4.27 \\
\hline Healthcare & 13.65 & 9.43 & 3.93 \\
\hline Education & 26.59 & 27.53 & 31.12 \\
\hline Public order, security & 3.43 & 4.44 & 3.57 \\
\hline Defence & 0.42 & 0.71 & 0.66 \\
\hline Public services & 4.50 & 4.00 & 4.20 \\
\hline
\end{tabular}

development and barriers to impede the development of SME, where local executive bodies play a key role.

Table 3 displays expenditures of local budgets in \%, in 2016-2018. Expenditures of local budgets look like this. Seven out of 13 items of expenditure make up $81.4 \%$ of all expenditures. In 2016 one out of every three tenge was allocated to education $(26.59 \%)$, healthcare - $13.65 \%$, housing and public utilities - $14.65 \%$, transportation and communication $-6.73 \%$, agriculture (water, forestry, fishing), protection of nature and land relations - $10.85 \%$, culture, sport, tourism $-4.72 \%$.

\section{DISCUSSION}

Budget reform refers to the improvement of principles that underlie budget regulation and inter-budget relations. Reform proposals are aimed at creating a transparent and effective system for public resources 
management. Its main function is to guide the budget system transition from one model of budgeting to another, with the economic policy geared towards achieving an optimal level of government spending (Parreiras et al., 2019). The budget structure implemented in a particular country complies with the form of government, federal or unitary. Therefore, the first classification attribute of budget reforms is the level at which the budgeting is committed (i.e., federal, regional, and local levels). Budgeting processes across different levels of government vary (1) in the range of issues raised during the reforming process; and (2) in matters that are governed. However, it is important to understand that if effective, budgeting strategies enable authorities to solve cross-industry and inter-territorial problems by consolidating budget resources at different levels and by attracting nongovernment sources.

The international experience proves not possible a rapid and successful transition to a holistic system of effective budget management in developing countries (Afonso \& Jalles, 2020). In most cases, budget reforms imply the individual formation of elements that together make up a new management system but the reforming period hence will last for a long period of time. Before or simultaneously with the fullscale implementation of a results-based budgeting system, the new methods for financial management and managerial results evaluation must be set in the framework.

Budgets are of particular importance to self-government bodies, which are the youngest branch of power of modern Kazakhstan. The first stage of reform of local self-government relates to the adoption of the Law of the Kazakh SSR of 15 February 1991 on "Local self-government and local
Soviets of people's deputies of the Kazakh SSR". It set out the basis for the development of local self-government, the material and financial base of the Soviets, the principle of the rule of representative bodies.

The next phase relates to the adoption of the Laws of 13 January 1992 on "Suspension of the separate rules of the Constitution of the Kazakh SSR during the transition period" and "Amendments and additions to the Law of the Kazakh SSR "On Local selfgovernment and local Soviets of people's deputies of the Kazakh SSR "for the transitional period". This document mentioned the suspension of the election of permanent commissions by the Soviets, the creation of executive and administrative, and other bodies accountable to them (Republic of Kazakhstan, 2016). The replacement of the beginning "the rule of representative bodies" for the principle of the division of functions and responsibilities of representative and executive-administrative bodies" constituted a novelty.

On 7 February 1992 the Decree of the President of the Republic of Kazakhstan on "Modernisation of the organisation and the activity of state administration bodies of the Republic of Kazakhstan under the conditions of economic reforms". For the first time, the unified system of executive-administrative bodies from the President of the Republic of Kazakhstan to heads of local administrations was enshrined in it. With the introduction of the institution of the head of the administration, the vertical system of executive power has been restored, but local representative bodies were still represented by the Soviets (Republic of Kazakhstan, 2016). Meanwhile, administrative bodies had practically full authority, the Soviets turned to an appendage of the local state mechanism, and there was no meaningful 
local self-government, which would have real power.

The first Constitution of the Republic of Kazakhstan, adopted on 28 January 1993 did not even include such a democratic institution of society as local selfgovernment. However, committees of public self-government, street, neighbourhood and quarter committees, which dealt with many social and household issues, utilities, ecological problems and etc., were established on the ground in many territorial communities.

On December 10, 1993, the Supreme Council of the Republic of Kazakhstan adopted the Law "Local representative and executive bodies of the Republic of Kazakhstan", which completed the formation of the unified system of state executive power.

On August 30, 1995, the current Constitution was adopted, it recognises local self-government, which is carried out by people directly through elections, as well as elective and other self-government bodies in rural and urban local communities, covering the territories, where compact groups of people live.

At the present, the operation of the system of local self-government in Kazakhstan is regulated by the Law of the Republic of Kazakhstan on "Local state government and self-government in the Republic of Kazakhstan", adopted on January 2001. Apart from this, with the adoption of novelties in 2017, this Law took into account the principle of decentralisation of functions, the aim of which is to rationalise the functions of state government, also the Law provides for the strengthening of independence and responsibility of local self-government bodies.

\section{CONCLUSIONS}

Consequently, the majority of expenditures of local budgets is intended to meet current needs, rather than focusing on technological or innovation development. The reason for such sharing of budget costs is lack of adequate participation and interest of local executive authorities in regional development and enhancing the capacity. As a result, we are faced with a paradoxical situation, in which strategic programmes and projects are designed at the republican level, programmes of industrial-innovation development are implemented, but at the local level these programmes are perceived as a possibility of using extra funds at best, and in the worst case, as something far from the real development of the region and having nothing to do with the current situation. The limitations of this study are the mismatch of the financial base of local selfgovernment, the insufficient number of financial resources and the inefficient legislative base for the formation of the local budget. Further studies may be aimed at preparing the necessary policy recommendations aimed at even distribution of the budget revenues between regions and an even distribution of local government functions between all levels of the executive branch. The results presented in this article differ from the results of other researchers, since they allow expanding the functions of akims of villages and thereby ensure their independence, contribute to the effective distribution of functions of local governance in the formation of budget funds. 


\title{
САВРЕМЕНИ ТРЕНДОВИ У УПРАВЉАЊУ БУЏЕТСКИМ СИСТЕМОМ
}

\section{Yerkezhan Bitoleuova, Dina Aibossynova, Gulmira Kabdullina, Manshuk Baimukhasheva, Raikhan Tazhibaeva}

\begin{abstract}
Извод
Чланак се бави тренутним фазама развоја локалне самоуправе у Републици Казахстан. Карактеристика реформи, које су у току, је јачање финансијске независности органа локалне самоуправе. Пре свега, то се приписује увођењу независног буџета на нивоу локалне самоуправе. Студија указује на системску природу буџетског процеса и анализира најбоље светске праксе реформи буџетског процеса. Систематски приступ помаже у откривању различитих карактеристика доношења буџетских одлука у контексту скупих и програмски планираних модела. Такође омогућава адекватно истраживање пословне климе и проналажење оптималних путева за развој. Резултати овог истраживања укључују аспекте и значај управљања буџетским системом Републике, на основу којих је изведен релевантан закључак.
\end{abstract}

Кључне речи: буџетски систем, буџетирање, иновација, локални буџет, локална самоуправа

\section{References}

Afanasyev, M., \& Krivogov, I. (2007). Modernization of public finances. Moscow, RU: Publishing House of the Higher School of Economics (in Russian).

Afanasyev, M.P. (2000), Prerequisites for the concept of a budget device and the budget process. Economic Issues, 11, 91-104 (in Russian).

Afonso, A., \& Jalles, J.T. (2020). Stock flow adjustments in sovereign debt dynamics: The role of fiscal frameworks. International Review of Economics \& Finance, 65, 1-16.

Asaubayev, R. (2016). Local government - development potential and current problems, Program for young researchers in the field of public policy of the Soros Foundation-Kazakhstan. Almaty, KZ: Soros.KZ (in Russian).

Committee of statistics of the MNE of the
$\mathrm{RK}$, in relation to GDP of the Republic of Kazakhstan. Available at: www.stat.gov.kz (accessed 22 October 2019).

Fomina, S.N., Sizikova, V.V., Shimanovskaya, Ya.V., Kozlovskaya, S.N., \& Karpunina, A.V. (2019). The effect of teaching and supply chain management on employees skills in small and medium sized enterprises of Russia. International Journal of Supply Chain Management, 8(4), 930938.

Igonina, L.L. (2003). Principles of the organization of local finance. Finance, 8, 1520. (in Russian).

International Monetary Fund (2007). Code of Good Practices on Fiscal Transparency. Available at: http://www.imf.org/external/np/fad/trans/rus /coder.pdf (accessed 22 October 2019).

International Monetary Fund (2007). Manual on Fiscal Transparency. Available at: http://www.imf.org/external/np/pp/2007/eng 
/101907m.pdf (accessed 22 October 2019).

Korikov, A.M., \& Pavlov, S.N. (2008). Theory of systems and systems analysis: textbook. allowance. Part 2. Tomsk: Tomsk state University of Control Systems and Electronics(in Russian).

Latysheva, V.V., Popova, O.V., Stolyarova, A.N., Pochestnev, A.A., Ishmuradova, I.I., \& Semenova, L.V. (2018). Municipal entity SWOT- analysis conducting appraisal to assess investment investment potential level. Espacios, 39 (1), 9-12.

Ministry of finance of the Republic of Kazakhstan. Available at: www.minfin.gov.kz (accessed 22 October 2019).

OECD, (2002). OECD Best Practices for Budget Transparency. Available at: http:/www.oecd.org/governance/budgeting/ Best Practices Budget Transparency complete with cover page.pdf (accessed 22 October 2019).

Parreiras, R.O., Kokshenev, I., Carvalho, M.O.M., Willerd, A.C.M., Dellezzopolles Jr., C.F., Nacif Jr., D.B., \& Santana, J.A. (2019). A flexible multicriteria decision-making methodology to support the strategic management of Science, Technology and Innovation research funding programs. European Journal of Operational Research, 272(2), 725-739.

Ponomareva, O. (2013). Tax optimization in budgeting. Accounting and Finance, 2 (80), 18-21(in Russian).

Razberg, B.A. (2009). State administration of economic and social processes. Moscow: INFRA-M (in Russian).

Republic of Kazakhstan (2016). About the republican budget for 2017-2019. Law of the Republic of Kazakhstan dated November 29, 2016 No. 25-VI ZRK. Available at: http://cis-legislation.com/document.fwx? rgn=91709 (accessed 22 October 2019).

Sabitova, N.M. (2002). Theoretical foundations of the budget of the Russian Federation. Finance, 6, 12-15 (in Russian).

Sabitova, N.M. (2004). Improving the forms and methods of financial support for constituent entities of the Russian Federation. Finance and Credit, 24, 2-10 (in Russian).

Sabitova, N.M. (2005). Some issues of reforming the budget process in the Russian Federation. Finance, 7, 71-73 (in Russian).

Vasilieva, M.V. (2011). Misuse of budget funds in regions and municipalities: causes, conditions, warning. Finance and Credit, 43 (475), 37-47 (in Russian).

Yan, Y.H., Hsu, Sh., Yang, Ch.W., \& Fang, Sh.Ch. (2010). Agency problems in hospitals participating in self-management project under global budget system in Taiwan. Health Policy, 94 (2), 135-143.

Zhunusova, R.M., Zhusupova, A.K., \& Utibaeva, G.B. (2014). Budget planning and forecasting. Almaty: Economy. 